\title{
Inequality at Low Levels of Aggregation in Chile*
}

\author{
Claudio A. Agostini and Philip H. Brown
}

August 2007

\begin{abstract}
Despite success in reducing poverty over the last twenty years, inequality in Chile has remained virtually unchanged, making Chile one of the least equal countries in the world. High levels of inequality have been shown to hamper further reductions in poverty as well as economic growth, and local inequality has been shown to affect such outcomes as violence and health. The study of inequality at the local level is thus crucial for understanding the economic well-being of a country. Local measures of inequality have been difficult to obtain, but recent theoretical advances have enabled the combination of survey and census data to generate estimates of inequality that are robust at disaggregated geographic levels. In this paper, we employ this methodology to produce consistent and precise estimates of inequality for every county in Chile. We find considerable heterogeneity in county-level estimates of inequality, with Gini coefficients ranging from 0.41 to 0.63 . An appendix includes estimated inequality for each county so the broader research community may assess the effect of local inequality on a broad range out outcomes, as well as analyze the determinants of inequality itself.
\end{abstract}

Keywords: inequality, poverty mapping, government subsidies, cash transfers, Chile

\footnotetext{
${ }^{*}$ We thank Chris Elbers, Berk Özler and Gabriel Demombynes for multiple clarifications and discussions regarding the methodology employed in this analysis. We are also grateful to Jason Long for programming help and to iSciences for map design and support. Financial support for this project was provided by the Universidad Alberto Hurtado and the Goldfarb Center for Public Affairs and Civic Engagement at Colby College. Philip H. Brown is also grateful to the International Food Policy Research Institute for sabbatical support during the preparation of this manuscript.
}

Agostini: Ilades-Universidad Alberto Hurtado, Erasmo Escala 1835, Santiago, Chile; agostini@uahurtado.cl Brown: Colby College, 5246 Mayflower Hill, Waterville, ME 04901, USA phbrown@ colby.edu 


\section{Introduction}

Between 1986 and 2005 per capita GDP in Chile grew by 203\%. The engine underlying this dramatic economic performance was a series of economic reforms begun in the mid-1970s, many of which were deepened during the 1990s (see, for example, Clapp 1995). Although privatization and deregulation were the hallmarks of these reforms, poverty reduction was also an important policy objective beginning in the early 1980s, and gains against poverty have been as impressive as Chile's growth statistics. Using a standardized form ${ }^{1}$ that evaluates housing characteristics to identify poor households, the government coupled housing subsidies with cash and in-kind transfers to the poor. ${ }^{2}$ Housing criteria were also used to identify locations for new schools and health care facilities. Chile thus took a multi-pronged approach to poverty reduction (Beyer 1997, Valdés 1999), and poverty rates fell from approximately $39.4 \%$ in 1987 to $18.7 \%$ in 2003; indigence rates also fell dramatically during this period, from approximately $14.2 \%$ to $4.7 \%$.

However, inequality has remained relatively constant during this period, and the Gini continues to be among the highest in the world (Contreras and Larrañaga, 1999; Ferreira and Litchfield, 1999; Contreras, Larrañaga, and Valdés, 2001; Contreras, 2003) despite the global trend towards convergence evident since the 1980s. For example, the Gini coefficient was 0.547 in 1987 and 0.546 in 2003 (Figure 1). Income inequality has been buoyed by low levels of migration (Soto and Torche 2004), uneven returns to education (Gindling and Robbins, 2001),

\footnotetext{
${ }^{1}$ The "CAS Card," renamed the "CAS-2 Card" after revisions in 1987.

${ }^{2}$ Such subsidies fall into five main categories: 1. Family Subsidy (SUF): A subsidy provided to pregnant women, parents with children not covered by social security, and parents or guardians of persons with physical disabilities. To be eligible, beneficiaries must agree to take children under age 6 for regular medical checkups and to send children aged 6 to 18 years to school; 2. Unemployment: A monthly payment for up to one year for unemployed workers who lost work through no fault of their own; 3. Assistance Pensions (PASIS): Pensions are provided for adults aged 65 and over, physically-disabled adults, and mentally-disabled individuals regardless of age who have a total income below half of the minimum pension allowance; 4. Solidarity Subsidy (Chile Solidario): A subsidy that targets indigent families and households with female heads. 5. Water and Sewage Subsidy (SAP): A three-year, renewable subsidy to offset the cost of water among poor households.
} 
foreign competition in labor-intensive goods (Beyer, Rojas, and Vergara, 1999), increased labor market participation among women (Contreras, Puentes, and Bravo, 2005), and an increasing reliance on seasonal and fixed-contract labor (Amuedo-Dorantes, 2005).

Inequality has been shown to have important effects on poverty, on social outcomes, and on public finance, and has thus become a growing concern for the public and policymakers alike. For example, for any given level of average income, greater inequality generally implies higher levels of poverty. Moreover, Ravallion $(1997,2004)$ shows that greater inequality causes poverty levels to fall at a lower rate. In terms of social outcomes, inequality at the local level impacts health, education, and the incidence of crime and violence (Deaton 1999). The levels and heterogeneity of local inequality may also impact tax collections and may influence the optimal degree of decentralization and provision of public goods (Bardhan and Mookherjee 1999).

National policies that target poverty reduction may have an impact on inequality. For example, progressive taxation and appropriately-targeted cash subsidies may reduce both poverty and income inequality. However, poverty-reduction programs may also raise inequality; as a case in point, improving the quality of education has been more effective in reducing poverty than expanding access to education (Chumacero and Paredes 2005), yet the resulting disparities in access raise income inequality. Similarly, Chile's generous housing subsidies have been effective at reducing poverty, yet they have also had the undesirable effect of tying individuals to their places of origin, thereby preventing migration to more productive areas with higher wages (Soto and Torche 2004).

Policy implementation may similarly affect inequality. On the one hand, local authorities have better information about local needs; on the other, they may be more susceptible to influence from vested interests and local elites (Bardhan and Mookherjee 2006). Elite capture of 
funding for poverty alleviation is difficult to test because detailed income data that are representative at low levels of aggregation are not available for most countries.

As with most countries, income data in Chile are derived from household surveys; although surveys such as the National Survey of Socioeconomic Characterization (Casen) contain detailed information on income and a wealth of other information for a large number of households, they are not representative at the sub-regional level. As a result, poverty and inequality in Chile have primarily been studied at the national and regional level (e.g., Contreras 1996; Contreras and Ruiz-Tagle 1997; Feres 2000; Contreras 2001; Pizzolito 2005a, 2005b) rather than at the sub-regional level of provinces or counties. Census data, by contrast, is representative at every level of aggregation (by definition), although they typically do not collect any information whatsoever about income. Censuses thus cannot not been used in the study of income inequality.

This problem has motivated research into methods for combining survey and census data in order to obtain geographically-disaggregated estimates of inequality. The sophistication of these methods has advanced a great deal in recent years, and it is now possible to obtain estimates that are statistically precise and reliable (e.g., Hentschel, et al.1999). ${ }^{3}$ In this paper, we adapt the methodology formalized by Elbers, Lanjouw, and Lanjouw (2003) to obtain estimates of inequality at the county-level in Chile. We find considerable heterogeneity in inequality among Chile's 341 counties and suggest that geographic considerations may be appropriate for policymakers who wish to address inequality. An appendix provides the estimated Gini coefficients and standard errors so that the broader research community may explore the impact

\footnotetext{
${ }^{3}$ This methodology has since been use to estimate wellbeing at the local level in Ecuador and Madagascar (Demombynes, et al. 2002), South Africa (Demombynes and Özler 2005), Mozambique (Elbers, et al. 2003), India (Kijima and Lanjouw 2003), and Cambodia (Elbers, et al. 2007).
} 
of precisely-estimated measures of inequality on a spectrum of socioeconomic outcomes, as well as the determinants of inequality itself.

The remainder of the paper is organized as follows: section 2 explains the methodology being used, both conceptually and in detail; section 3 provides a detailed description of the data; section 4 presents the results with detailed maps describing inequality at the county level; and section 5 offers a brief conclusion and suggestions for further research.

\section{Methodology}

The intuition behind the methodology proposed by Hentschel, et al.(1999) and developed by Elbers, Lanjouw, and Lanjouw (2003) is conceptually straightforward: a model of income or consumption is first estimated using survey data, restricting the explanatory variables to those also available in both the survey and a census undertaken at a similar point in time. These parameters are then used to estimate income or consumption for the entire population based on the census data. Finally, poverty and inequality indicators are estimated for geographic areas for which the census is representative but for which the survey is not.

Statistically, the methodology consists of estimating the joint distribution of the income or consumption and a vector of explanatory variables. Restricting the set of explanatory variables to those available in the census, the estimated joint distribution can be used to generate the distribution of the variable of interest for any subgroup of the population in the census, conditional to the observed characteristics of that subgroup. This also allows for the generation of a conditional distribution, point estimates, and prediction errors of the associated indicators such as poverty and inequality. 
In a first stage, a model is created that relates the income per capita of household $h\left(Y_{h}\right)$ in cluster $c$ with a group of observable characteristics $\left(X_{h}\right)$ :

$$
\ln Y_{h c}=E\left[\ln Y_{h c} \mid X_{h c}\right]+u_{h c}=X_{h c}+u_{h c}
$$

where the error vector $u$ is distributed $\Gamma(0, \Sigma)$. To allow correlation within each cluster, the error term is further assumed to consist of a cluster component $(\eta)$ and an idiosyncratic error $(\varepsilon)$ :

$$
u_{h c}=\eta_{c}+\varepsilon_{h c}
$$

The two components are assumed to be independent of each other and uncorrelated with the observable variables $X_{h c}$.

It is not necessary to specify a restrictive functional form for the idiosyncratic component of the error, $\sigma_{\varepsilon}^{2}$. Indeed, with consistent estimators of $\beta$, the residuals of the decomposition of the estimated error,

$$
\hat{u}_{h c}=\hat{u}_{. c}+\left(\hat{u}_{h c}-\hat{u}_{. c}\right)=\hat{\eta}_{c}+\hat{\varepsilon}_{h c}
$$

can be used to estimate the variance of $\varepsilon .^{4}$ The functional form commonly used for estimating the variance of the idiosyncratic error is:

\footnotetext{
${ }^{4}$ The subindex "." in the equation represents the average over the index.
} 


$$
\sigma_{\varepsilon}^{2}=\left[\frac{A \hat{\varepsilon}^{z_{h c}^{T} \alpha}+B}{1+\hat{\varepsilon}^{z_{h c}^{T} \alpha}}\right]
$$

The upper and lower limits, $A$ and $B$, can be estimated together with the parameter $\alpha$ using the standard pseudo-maximum likelihood; the advantage of this approach is that it eliminates negative and excessively high values for the predicted variances.

The simplest means of estimating the model is to use a linear approximation of the conditional expectation, allowing geographic effects and heteroskedasticity into the distribution of the error term. It is important to note that the cluster component of the residual can significantly reduce the power of the estimates in the second stage, and that it is thus important to explain the variation in income or consumption due to location via observable variables to the greatest extent possible.

The result of this first-stage estimation is a vector of coefficients, $\beta$, a variancecovariance matrix associated with this vector, and a set of parameters that describe the distribution of the errors. The second stage utilizes this set of parameters along with the characteristics of the individuals or households in the census in order to generate predicted values of the log of income and the relevant errors. For these effects, a bootstrap method is used to simulate values of income of each household or each individual. These simulated values are based on the prediction of the income and the error terms, $\eta$ and $\varepsilon$ :

$$
\hat{Y}_{h c}=\exp \left(X_{h c} \hat{\beta}+\hat{\eta}_{c}+\hat{\varepsilon}_{h c}\right)
$$


For each household, the two components of the error term are taken from the empirical distribution described by the parameters estimated in the first stage. The coefficients $\hat{\beta}$, are taken from the normal multivariate distribution described by the estimators of $\beta$ in the first stage and the associated variance-covariance matrix. The complete set of simulated values of $\hat{Y}_{h c}$ is then used to calculate the expected value of poverty or inequality measures by area. This procedure is repeated $n$ times, taking a new set of coefficients $\beta$ and errors for each simulation; the mean and the standard deviations of the $\beta$ s constitute the point estimates and the standard deviations for the wellbeing indicator, respectively.

We will call the inequality indicator $G\left(n_{c}, X_{c}, \beta, u_{c}\right)$, where $n_{c}$ is a $N_{c}$ vector of the number of household members in county $c, X_{c}$ is a $N_{c} x k$ vector of their observable characteristics, and $u_{c}$ is a $N_{c}$ error vector. Thus, the expected value of the inequality indicator is estimated given the characteristics of the individuals and the households and the model estimated in the first stage, i.e.:

$$
G_{c}^{E}=E[G \mid n, X ; \xi]
$$

where $\xi$ is the vector of parameters of the model, including the parameters that describe the distribution of the error term. Replacing the unknown vector $\xi$, with a consistent estimator $\hat{\xi}$, we get:

$$
G_{c}^{E}=E[G \mid n, X, \hat{\xi}]
$$


This conditional expected value is generally impossible to resolve analytically, making it necessary to use Monte Carlo simulations to obtain an estimator $\widetilde{G}_{c}^{E}$.

One complication associated with this methodology is calculating the correct standard errors, which is not trivial. Because it is not possible to calculate them analytically, we again resort to bootstrapping techniques and Monte Carlo simulations. Suppressing the subscripts, the difference between the estimator of the expected value of $G, \tilde{G}_{c}^{E}$, and the actual level of the inequality indicator for the geographic area can be decomposed into:

$$
G-\tilde{G}^{E}=\left(G-G^{E}\right)+\left(G^{E}-\hat{G}^{E}\right)+\left(\hat{G}^{E}-\tilde{G}^{E}\right)
$$

The prediction error thus has three components: the first is due to the presence of a stochastic error in the first stage model, implying that the actual household incomes deviate from their expected values (idiosyncratic error); the second is due to the variance in the estimators of the parameters of the model from the first stage (model error); and the third is due to the use of an inexact method to calculate $\hat{G}_{c}$ (calculation error).

The variance of the estimator due to the idiosyncratic error shrinks proportionally with the population in each geographic area. Thus, smaller populations within each geographic area are associated with larger idiosyncratic errors, introducing a limit to the extent of disaggregation that may be achieved. The variance of the estimator due to the model error can be calculated using the delta method:

$$
V_{\text {Model }}=\nabla^{T} V(\hat{\xi}) \nabla
$$


where $\nabla=\left\lfloor\partial G^{E} / \partial \xi\right], V(\xi)$ is the variance-covariance matrix of the first stage estimators, and $\hat{\xi}$ is a consistent estimator of $\xi$, also obtained from the first stage. This component of the predicted errors is determined by the properties of the first-stage estimators and therefore doesn't systematically change with the population in each geographic area; its magnitude depends only on the precision of the first-stage estimates. The variance of the estimator due to computational error depends on the computational methodology used. Since Monte Carlo simulations are employed here, it is possible to reduce this error component by increasing the number of simulations; we use 250 simulations to minimize the error component to the greatest extent possible.

The expected value of the inequality indicator coefficient is thus conditional on the first stage regression, the variance due to the idiosyncratic component of income per capita of the households, and the gradient vector. The Monte Carlo simulation generates 250 vectors of error terms from the distribution estimated in the first stage. With each set of vectors, the inequality indicator is calculated. Then, the expected value simulated for the inequality indicator is the average of the 250 responses:

$$
\tilde{G}^{E}=\frac{1}{250} \sum_{d=1}^{250}\left(\hat{G}_{d}^{E}\right)
$$

The variance of $G$ is estimated using the same simulated values, such that:

$$
V_{\text {Model }}=\frac{1}{250} \sum_{d=1}^{250}\left(G_{d}-\tilde{G}^{E}\right)^{2}
$$


Finally, it is important to underscore the crucial assumption that the models estimated using survey data are applicable to the observations of the census. This assumption is reasonable enough if the year of the census and the survey coincide or are close. In the case of this particular study, the 2002 census is matched with the 2003 Casen survey, making the assumption implicit in the methodology reasonable.

\section{Data}

The survey employed in the first stage of the methodology described above is the November 2003 National Survey of Socioeconomic Characterization (Casen). The data collected include demographic characteristics for the household members, distinct sources of income including state transfers, living conditions, ownership of certain durable goods, access to sanitation, and health and education characteristics. The Casen survey is undertaken by the Ministry of Planning (Mideplan), but the data are adjusted by the Economic Commission for Latin America and the Caribbean (ECLAC) using a system of national accounts as a reference. These adjustments consider the problems generated by the lack of income data for some households and the under or over representation of some income categories in the sample. ${ }^{5}$

The survey utilizes a multistage method of random sampling with stratification. In the first stage, the country was divided between rural and urban areas for each of the 13 regions, and the primary sampling units are selected with probabilities proportional to the population. In the second stage, households are selected into the sample with equal probability. The final sample includes 68,153 households comprising 257,077 people. These households represent 315 of the

\footnotetext{
${ }^{5}$ Although the ECLAC adjustments could generate some bias, Contreras and Larrañaga 1999 present evidence to the contrary. Regardless, the unadjusted data are not available.
} 
342 counties in Chile, with as few as 49 and as many as 315 households surveyed in each county. While coverage of counties in northern and central Chile is nearly complete, the survey poorly represents counties in southern Chile. Although Mideplan considers the Casen to be representative at the regional level and for 301 self-reporting counties, there is no consensus with respect to the validity of the county representativeness, and various researchers consider the representativeness to be only national and regional (e.g., Valdés 1999; Contreras, et al. 2001; Pizzolito 2005a, 2005b).

Using the Casen alone to calculate inequality yields results that allow for very few conclusions given the magnitude of the errors, a problem that persists at the regional level as well as the county level. For example, the Gini coefficient estimated by the Casen for the Region I is 0.495 , but with a standard error of 0.053 , the $95 \%$ confidence interval ranges from 0.392 to 0.599. The evidence presented in the results section below as well as those obtained from similar studies in other countries show that the standard errors obtained by imputing income to census data are much lower than those obtained using survey data (Elbers et al., 2003).

The National Institute of Statistics conducts a population and housing census every ten years, the most recent (and that used in this analysis) being undertaken in April 2002. The census covered 4,112,838 households composed of 15,545,921 individuals. The data include demographic characteristics, labor status, educational level, ownership of certain assets, access to basic sanitation, and migration activities during the previous ten years, but neither income nor consumption.

To impute income data into the census, a set of explanatory variables common to both the Casen and the census must be identified. Although some explanatory variables are defined identically in both data sets, others were constructed, the means and variances of both types of 
variables were evaluated to ensure that the explanatory variables from the census are indeed the same as those in the Casen. Using step-wise regression to detect the best fit for each region, we determined that household demographics, characteristics of the household head, characteristics of the house itself, and assets were the strongest predictors of household income. The model estimated in the first stage may thus be written:

$$
\ln Y_{h c}=\beta_{0}+\beta_{1} D+\beta_{2} H+\beta_{3} V+\beta_{4} A+u_{h c}
$$

where the dependent variable $Y_{h c}$ is total per capita income of the household. $D$ is a vector of the demographic characteristics, including the number of household members and the fraction household membership that is below school-age. $H$ is a vector of characteristics of the head of household that includes gender, education level, and ethnicity. $V$ is a vector of characteristics of the house itself, including the number of rooms, the principal construction material of the house, the type of flooring, the primary water source, and the distribution system of water. $A$ is a vector of dummy variables that describes the ownership of various assets, including a washing machine, hot water heater, land line telephone, cellular phone, satellite or cable television, microwave, computer, and Internet access. Additionally, location dummy variables are included to control for unobserved heterogeneity.

It is important to note that the objective of this first-stage regression is not to determine causality, but rather to make the best possible prediction of per capita income based on observable characteristics of each household. Given that the observable predictors vary across Chile's 13 regions, separate regressions are estimated for each. In each, county dummies variables were also included to capture the local geographic effects. 


\section{Results}

From the coefficients and the variance-covariance matrix estimated in the first stage, the methodology described above is used to estimate the Gini coefficient of each county within each region together with its respective standard error. ${ }^{6}$ Gini coefficients range from 0.409 in Pumanque county (Region VI) to 0.627 in San Fabián county (Region VIII).

Figure 2 shows the distribution of inequality, measured by the Gini coefficient, in northern Chile, Regions I (Tarapacá), II (Antofogasta), III (Atacama), and IV (Coquimbo). The counties with the highest estimated inequality in northern Chile are La Serena in Region IV and Iquique in Region I, with estimated Gini coefficients of 0.502 (standard error of 0.008) and 0.487 (standard error of 0.007), respectively. Conversely, the counties with the lowest inequality are La Higuera and Andacollo, both in Region IV, with Gini coefficients of 0.424 (standard error of 0.010 ) and 0.442 (standard error of 0.007 ).

Figure 3 depicts estimated inequality in Regions VI (O’Higgins), VII (Maule), VII (BíoBío), and IX (Araucanía). As noted above, the extremes values for estimated inequality are found in central Chile. The counties with the highest levels of inequality are San Fabián and San Pedro de la Paz, both in Region VIII, with Gini coefficients of 0.607 (standard error of 0.040) and 0.541 (standard error of 0.005), respectively. The counties with the lowest estimated Gini coefficients are Pumanque and Paredones, both in Region VI, with Gini coefficients of 0.410 (standard error of 0.010 ) and 0.413 (standard error of 0.008 ).

\footnotetext{
${ }^{6}$ Although the methodology is identical for any common indicator of inequality, we choose to focus on the Gini coefficient is used for two reasons. First, the Gini coefficient is widely used measure and generally well understood. Second, experiments and surveys that measure aversion to inequality empirically have shown that a function of wellbeing based on the Gini coefficient presents a much better description of the data than measures based on the absolute or relative aversion to inequality (Amiel, Creedy, and Hurn 1999).
} 
Figure 4 depicts inequality in southern Chile, including Regions X (Los Lagos), XI (Aisén), and XII (Magallanes). Here, Río Verde and Primavera in Region XII display the highest levels of income inequality, with estimated Gini coefficients of 0.541 (standard error of 0.040 ) and 0.534 (standard error of 0.020), respectively. The counties with the lowest inequality are San Juan de la Costa and Puqueldón, both in Region X, with Gini coefficients of 0.433 (standard error of 0.007 ) and 0.446 (standard error of 0.010 ).

Finally, Figure 5 shows the distribution of inequality for Regions V (Valparaíso) and XIII (the Santiago Metropolitan Region). Here, the districts with the greatest inequality are Calera de Tango and Colina with Gini coefficients of 0.54 and 0.53 , respectively, both in Region XIII. The districts with the least inequality are Juan Fernández in Region V and Vitacura in Region XIII, both of which have estimated Gini coefficients of 0.43 . The relative homogeneity of income within these two wealthy counties is noteworthy, as is the equality of incomes across Region V, wherein estimated Gini coefficients range from 0.43 to 0.47 .

These inequality maps show that heterogeneity in county-level inequality is high. Figure 6 underscores this observation by showing the distribution of Gini coefficients for each county in Chile with its respective confidence intervals. Also included in the graph is a line representing the national Gini coefficient according to the Casen survey. Comparing the distribution of the county Gini coefficients to the national Gini coefficient shows that all but two counties have levels of inequality below the national level. This shows that although the inequality between counties is very important, there also exists a considerable amount of variation between the households within each county. This result is not at all surprising - the evidence from Ecuador, Madagascar and Mozambique is similar (Demombynes, et al. 2002) - and simply reflects that local communities are more homogeneous than Chile as a whole. 
Perhaps the best way to represent the variability of inequality is to estimate its distribution. Figure 7 thus shows a histogram of the Gini coefficients together with a Kernel estimation for the distribution. As the figure shows, the estimated empirical distribution is not symmetrical and there is a greater proportion of counties with relatively more inequality, with respect to the average, than counties with less inequality. ${ }^{7}$ In the future, it would be interesting to repeat the exercise using the 1992 census and the 1992 Casen survey. This would allow a comparison of two inequality distributions with ten years of difference to better understand the evolution of inequality at the local level.

\section{Conclusion and Discussion}

The principal objective of this work was to produce disaggregated estimates of inequality for Chile. This was achieved by applying the methodology developed by Hentschel, et al.(1999) and Elbers, et al. (2003) to the Chilean context using the 2002 population census and the 2003 Casen survey. We find that income inequality at the county level is much lower than national estimates of income inequality, although there is considerable heterogeneity in inequality among counties. This suggests that between-county inequality is driving Chile's high and persistent income inequality.

The estimates developed in this paper make it possible to extend the analysis of income distribution at the regional level exemplified by Contreras (1996) and Contreras and Ruiz-Tagle (1997) to sub-regional units. Another application for which the estimates have obvious use is to develop better targeting for policies aimed at reducing poverty and inequality; such interventions may prove more effective than existing efforts in reducing Chile's high income inequality. In addition, the estimates may be used to analyze the effect of poverty on a wide spectrum of social

\footnotetext{
${ }^{7}$ For this reason, nonparametric estimation was used when implementing the estimation methodology.
} 
outcomes for which local measures of inequality are more likely to have an impact than national measures of inequality, e.g., health and crime (Deaton 1999). Finally, the estimates enable further research into the effects of local income inequality on public finance, including the diversion of funds for poverty reduction to local elites (Bardhan and Mookherjee, 2005). 


\section{References}

Amuedo-Dorantes, C. (2005), "Wage Contracts and Earnings Inequality: The Case of Chile." Journal of Development Studies 41(4): 589-616.

Bardhan, P. and D. Mookherjee (2006). "Relative Capture of Local and Central Governments: An Essay in the Political Economy of Decentralization," Working Paper 1013, Center for International and Development Economics Research, Institute for Business and Economic Research, UC Berkeley.

Beyer, H. (1997), “Distribución del Ingreso: Antecedentes para la Discusión”. Estudios Públicos 65: 5-58.

Beyer, H., P. Rojas, and R. Vergara, (1999), "Trade Liberalization and Wage Inequality." Journal of Development Economics 59(1): 103-123.

Chumacero, R. A. and R. D. Paredes (2004), "Characterizing Income Distribution for Poverty and Inequality Analysis.” Estudios de Economía 32(1): 97-117.

Clapp, R. A. (1995), "Creating Competitive Advantage: Forest Policy as Industrial Policy in Chile.” Economic Geography 71(3): 273-296.

Contreras, D. (2001), "Economic Growth and Poverty Reduction by Region: Chile 1990-96", Development Policy Review 19(3).

Contreras, D. (2003), "Poverty and Inequality in a Rapid Growth Economy: Chile 1990-96", Journal of Development Studies 39(3).

Contreras, D. (1996), "Pobreza and Desigualdad en Chile: 1987-1992. Discurso, Metodología y Evidencia Empírica”, Estudios Públicos 64, Spring.

Contreras, D. and O. Larrañaga (1999), “Activos y Recursos de la Población Pobre en Chile”, El Trimestre Económico 66(263).

Contreras, D., O. Larrañaga, J. Litchfield and A. Valdés (2001), "Poverty and Income Distribution in Chile 1987-1998: New Evidence",Cuadernos de Economía 114.

Contreras, D. and J. Ruiz-Tagle (1997), "Como Medir la Distribución del Ingreso en Chile", Estudios Públicos 65.

Contreras, D., E. Puentes, and D. Bravo (2005), "Female Labor Force Participation in Greater Santiago, Chile: 1957-1997. A Synthetic Cohort Analysis." Journal of International Development 17(2): 169-186.

Deaton, A. (2001), "Inequalities in Income and Inequalities in Health", en F. Welch (ed.) The Causes and Consequences of Increasing Inequality, The University of Chicago Press.

Demombynes, G., C. Elbers, J. Lanjouw, P. Lanjouw, J. Mistiaen and B. Özler (2002), "Producing an Improved Geographic Profile of Poverty", World Institute for Development Economics Research Discussion Paper No.2002-39.

Demombynes, G. and B. Özler (2005), "Crime and Local Inequality in South Africa", Journal of Development Economics 76(2).

Elbers, Chris, J.O. Lanjouw and Peter Lanjouw. (2003) "Micro-Level Estimation of Poverty and Inequality", Econometrica, Vol. 71, No.1. 
Elbers, C., P Lanjouw, J. Mistiaen, B. Özler and K. Simler (2003), “Are Neighbours Equal?", World Institute for Development Economics Research Discussion Paper No. 2003-52

Elbers, C., P Lanjouw, J. Mistiaen, B. Özler and K. Simler (2004), "On the Unequal Inequality of Poor Communities", World Bank Economic Review 18(3).

Elbers, C., T. Fujii, P. Lanjouw, B. Özler, and W. Yin (2007), "Poverty Alleviation Through Geographic Targeting: How Much Does Disaggregation Help?", Journal of Development Economics, 83.

Feres, J.C. (2000), “La Pobreza en Chile en el año 2000”, Serie Estudios Estadísticos y Prospectivos No. 14, CEPAL.

Ferreira, F. and J. A. Litchfield (1999), "Calm after the Storms: Income Distribution and Welfare in Chile 1987-1994", World Bank Economic Review 13(3).

Gindling, T.H. and D. Robbins, (2001). "Changes and Patterns of Changing Wage Inequality in Chile and Costa Rica During Structural Adjustment." World Development 29(4): 725-745.

Hentschel, J., J. Lanjouw, P. Lanjouw and J. Poggi (1999), Combining Survey Data with Census Data to Construct Spatially Disaggregated Poverty Maps: A Case Study of Ecuador, World Economic Bank Review, Vol. 14, No.1.

Kijima, Y. and P. Lanjouw (2003), "Poverty in India During the 1990s: A Regional Perspective" The World Bank, DECRG Working Paper.

Pizzolito, G. (2005a), "Monitoring Socio-Economic Conditions in Argentina, Chile, Paraguay, and Uruguay: Chile", CEDLAS-World Bank Report, December.

Pizzolito, G. (2005b), "Poverty and Inequality in Chile: Methodological Issues and a Literature Review", Documento de Trabajo No. 20, CEDLAS.

Ravallion, M. (1997), “Can High Inequality Development Countries Escape Absolute Poverty?", Economics Letters 56.

Ravallion, M. (2004), "Pro-Poor Growth: A Primer", The World Bank, Policy Research Working Paper No. 3242.

Soto, R. and A. Torche (2004), "Spatial Inequality, Growth, and Migration in Chile." Cuadernos de Economía 41: 401-424.

Valdés, A. (1999), "Pobreza y Distribución del Ingreso en una Economía de Alto Crecimiento: Chile, 1987-1995”, Estudios Públicos 75. 


\section{Appendix}

This appendix prsents the estimated Gini coefficients and standard errors for each of Chile's 341

counties. All estimates are based on the methodology proposed by Elbers, et al. (2003).

\begin{tabular}{|c|c|c|c|c|c|c|c|c|c|}
\hline Reg. & County & $\begin{array}{c}\text { Census } \\
\text { Code }\end{array}$ & $\begin{array}{c}\text { Gini } \\
\text { Coef. } \\
\end{array}$ & $\begin{array}{c}\text { Std. } \\
\text { Error }\end{array}$ & Reg. & County & $\begin{array}{c}\text { Census } \\
\text { Code }\end{array}$ & $\begin{array}{r}\text { Gini } \\
\text { Coef. } \\
\end{array}$ & $\begin{array}{l}\text { Std. } \\
\text { Error }\end{array}$ \\
\hline I & Iquique & 1101 & 0.4809 & 0.00580 & VIII & San Rosendo & 8310 & 0.4673 & 0.01260 \\
\hline I & Camiña & 1102 & 0.4796 & 0.01813 & VIII & Santa Bárbara & 8311 & 0.4849 & 0.00656 \\
\hline I & Colchane & 1103 & 0.4947 & 0.02219 & VIII & Tucapel & 8312 & 0.4832 & 0.01053 \\
\hline I & Huara & 1104 & 0.4874 & 0.01354 & VIII & Yumbel & 8313 & 0.4701 & 0.00586 \\
\hline I & Pica & 1105 & 0.4880 & 0.01209 & VIII & Chillán & 8401 & 0.5130 & 0.00392 \\
\hline I & Pozo Almonte & 1106 & 0.4806 & 0.00938 & VIII & Bulnes & 8402 & 0.4897 & 0.00961 \\
\hline I & Arica & 1201 & 0.4829 & 0.00604 & VIII & Cobquecura & 8403 & 0.4681 & 0.01006 \\
\hline I & Camarones & 1202 & 0.4857 & 0.01824 & VIII & Coelemu & 8404 & 0.4749 & 0.00714 \\
\hline I & Putre & 1301 & 0.4735 & 0.01587 & VIII & Coihueco & 8405 & 0.4659 & 0.00559 \\
\hline I & General Lagos & 1302 & 0.4828 & 0.02196 & VIII & Chillán Viejo & 8406 & 0.4888 & 0.00701 \\
\hline II & Antofagasta & 2101 & 0.4689 & 0.00712 & VIII & El Carmen & 8407 & 0.4543 & 0.00617 \\
\hline II & Mejillones & 2102 & 0.4503 & 0.00928 & VIII & Ninhue & 8408 & 0.4596 & 0.01349 \\
\hline II & Sierra Gorda & 2103 & 0.4720 & 0.02039 & VIII & Ñiquén & 8409 & 0.4519 & 0.00688 \\
\hline II & Taltal & 2104 & 0.4584 & 0.00873 & VIII & Pemuco & 8410 & 0.4526 & 0.00805 \\
\hline II & Calama & 2201 & 0.4683 & 0.00732 & VIII & Pinto & 8411 & 0.4692 & 0.00771 \\
\hline II & Ollague & 2202 & 0.4659 & 0.04078 & VIII & Portezuelo & 8412 & 0.4775 & 0.01365 \\
\hline II & San Pedro de Atacama & 2203 & 0.4759 & 0.01081 & VIII & Quillón & 8413 & 0.4673 & 0.00651 \\
\hline II & Tocopilla & 2301 & 0.4737 & 0.01037 & VIII & Quirihue & 8414 & 0.4780 & 0.00727 \\
\hline II & María Elena & 2302 & 0.4572 & 0.01586 & VIII & Ránquil & 8415 & 0.4614 & 0.01068 \\
\hline III & Copiapo & 3101 & 0.4791 & 0.00696 & VIII & San Carlos & 8416 & 0.5044 & 0.00969 \\
\hline III & Caldera & 3102 & 0.4670 & 0.00904 & VIII & San Fabián & 8417 & 0.6360 & 0.08344 \\
\hline III & Tierra Amarilla & 3103 & 0.4695 & 0.01634 & VIII & San Ignacio & 8418 & 0.4542 & 0.00688 \\
\hline III & Chañaral & 3201 & 0.4709 & 0.00983 & VIII & San Nicolás & 8419 & 0.4567 & 0.00797 \\
\hline III & Diego de Almagro & 3202 & 0.4846 & 0.00849 & VIII & Treguaco & 8420 & 0.4409 & 0.00978 \\
\hline III & Vallenar & 3301 & 0.4833 & 0.00698 & VIII & Yungay & 8421 & 0.4903 & 0.00659 \\
\hline III & Alto del Carmen & 3302 & 0.4647 & 0.01079 & IX & Temuco & 9101 & 0.5321 & 0.00651 \\
\hline III & Freirina & 3303 & 0.4607 & 0.01044 & IX & Carahue & 9102 & 0.4773 & 0.00649 \\
\hline III & Huasco & 3304 & 0.4712 & 0.00956 & IX & Cunco & 9103 & 0.4633 & 0.00558 \\
\hline IV & La Serena & 4101 & 0.5024 & 0.00778 & IX & Curarrehue & 9104 & 0.4634 & 0.00934 \\
\hline IV & Coquimbo & 4102 & 0.4852 & 0.00666 & IX & Freire & 9105 & 0.4646 & 0.00690 \\
\hline IV & Andacollo & 4103 & 0.4432 & 0.00748 & IX & Galvarino & 9106 & 0.4679 & 0.00708 \\
\hline IV & La Higuera & 4104 & 0.4245 & 0.01021 & IX & Gorbea & 9107 & 0.4724 & 0.00643 \\
\hline IV & Paiguano & 4105 & 0.4570 & 0.01037 & IX & Lautaro & 9108 & 0.5088 & 0.00636 \\
\hline IV & Vicuña & 4106 & 0.4658 & 0.00727 & IX & Loncoche & 9109 & 0.4745 & 0.00557 \\
\hline IV & Illapel & 4201 & 0.4745 & 0.00711 & IX & Melipeuco & 9110 & 0.4671 & 0.01029 \\
\hline IV & Canela & 4202 & 0.4469 & 0.00753 & IX & Nueva Imperial & 9111 & 0.4835 & 0.00532 \\
\hline IV & Los Vilos & 4203 & 0.4745 & 0.00766 & IX & Padre las Casas & 9112 & 0.4794 & 0.00474 \\
\hline IV & Salamanca & 4204 & 0.4736 & 0.00856 & IX & Perquenco & 9113 & 0.4783 & 0.01302 \\
\hline IV & Ovalle & 4301 & 0.4736 & 0.00535 & IX & Pitrufquén & 9114 & 0.4871 & 0.00751 \\
\hline IV & Combarbalá & 4302 & 0.4584 & 0.00698 & IX & Pucón & 9115 & 0.5019 & 0.00649 \\
\hline IV & Monte Patria & 4303 & 0.4470 & 0.00670 & IX & Saavedra & 9116 & 0.4539 & 0.00685 \\
\hline IV & Punitaqui & 4304 & 0.4487 & 0.00743 & IX & Teodoro Schmidt & 9117 & 0.4617 & 0.01558 \\
\hline IV & Río Hurtado & 4305 & 0.4552 & 0.01086 & IX & Toltén & 9118 & 0.4712 & 0.00812 \\
\hline V & Valparaíso & 5101 & 0.4441 & 0.00298 & IX & Vilcún & 9119 & 0.4743 & 0.00596 \\
\hline $\mathrm{V}$ & Casablanca & 5102 & 0.4376 & 0.00512 & IX & Villarrica & 9120 & 0.4967 & 0.00594 \\
\hline $\mathrm{V}$ & Concón & 5103 & 0.4620 & 0.00481 & IX & Angol & 9201 & 0.5222 & 0.00639 \\
\hline $\mathrm{V}$ & Juan Fernández & 5104 & 0.4255 & 0.02248 & IX & Collipulli & 9202 & 0.4846 & 0.00617 \\
\hline
\end{tabular}




\begin{tabular}{|c|c|c|c|c|c|c|c|c|c|}
\hline Reg. & County & $\begin{array}{c}\text { Census } \\
\text { Code }\end{array}$ & $\begin{array}{c}\text { Gini } \\
\text { Coef. }\end{array}$ & $\begin{array}{l}\text { Std. } \\
\text { Error }\end{array}$ & Reg. & County & $\begin{array}{c}\text { Census } \\
\text { Code }\end{array}$ & $\begin{array}{l}\text { Gini } \\
\text { Coef. }\end{array}$ & $\begin{array}{l}\text { Std. } \\
\text { Error }\end{array}$ \\
\hline $\mathrm{V}$ & Puchuncaví & 5105 & 0.4350 & 0.00590 & IX & Curacautín & 9203 & 0.5007 & 0.00700 \\
\hline $\mathrm{V}$ & Quilpué & 5106 & 0.4406 & 0.00352 & IX & Ercilla & 9204 & 0.4637 & 0.00833 \\
\hline $\mathrm{V}$ & Quintero & 5107 & 0.4468 & 0.00549 & IX & Lonquimay & 9205 & 0.4748 & 0.00794 \\
\hline $\mathrm{V}$ & Villa Alemana & 5108 & 0.4376 & 0.00349 & IX & Los Sauces & 9206 & 0.5013 & 0.02288 \\
\hline $\mathrm{V}$ & Viña del Mar & 5109 & 0.4594 & 0.00374 & IX & Lumaco & 9207 & 0.4767 & 0.00829 \\
\hline $\mathrm{V}$ & Isla de Pascua & 5201 & 0.4421 & 0.01035 & IX & Purén & 9208 & 0.4887 & 0.00724 \\
\hline $\mathrm{V}$ & Los Andes & 5301 & 0.4481 & 0.00387 & IX & Renaico & 9209 & 0.4685 & 0.00875 \\
\hline $\mathrm{V}$ & Calle Larga & 5302 & 0.4397 & 0.00778 & IX & Traiguén & 9210 & 0.5219 & 0.00768 \\
\hline $\mathrm{V}$ & Rinconada & 5303 & 0.4337 & 0.00795 & IX & Victoria & 9211 & 0.5168 & 0.00646 \\
\hline $\mathrm{V}$ & San Esteban & 5304 & 0.4354 & 0.00594 & $\mathrm{X}$ & Puerto Montt & 10101 & 0.5029 & 0.00582 \\
\hline $\mathrm{V}$ & La Ligua & 5401 & 0.4404 & 0.00476 & $\mathrm{X}$ & Calbuco & 10102 & 0.4650 & 0.00519 \\
\hline $\mathrm{V}$ & Cabildo & 5402 & 0.4342 & 0.00503 & $\mathrm{X}$ & Cochamó & 10103 & 0.4496 & 0.01001 \\
\hline $\mathrm{V}$ & Papudo & 5403 & 0.4333 & 0.00922 & $\mathrm{X}$ & Fresia & 10104 & 0.4615 & 0.00637 \\
\hline V & Petorca & 5404 & 0.4269 & 0.00684 & $\mathrm{X}$ & Frutillar & 10105 & 0.4895 & 0.00722 \\
\hline $\mathrm{V}$ & Zapallar & 5405 & 0.4297 & 0.00788 & $\mathrm{X}$ & Los Muermos & 10106 & 0.4761 & 0.01689 \\
\hline $\mathrm{V}$ & Quillota & 5501 & 0.4463 & 0.00365 & $\mathrm{X}$ & Llanquihue & 10107 & 0.4924 & 0.00638 \\
\hline $\mathrm{V}$ & Calera & 5502 & 0.4409 & 0.00379 & $\mathrm{X}$ & Maullín & 10108 & 0.4490 & 0.00544 \\
\hline $\mathrm{V}$ & Hijuelas & 5503 & 0.4269 & 0.00501 & $\mathrm{X}$ & Puerto Varas & 10109 & 0.5262 & 0.00879 \\
\hline V & La Cruz & 5504 & 0.4484 & 0.00686 & $\mathrm{X}$ & Castro & 10201 & 0.4973 & 0.00569 \\
\hline $\mathrm{V}$ & Limache & 5505 & 0.4440 & 0.00430 & $\mathrm{X}$ & Ancud & 10202 & 0.4824 & 0.00447 \\
\hline $\mathrm{V}$ & Nogales & 5506 & 0.4336 & 0.00505 & $\mathrm{X}$ & Chonchi & 10203 & 0.4761 & 0.00742 \\
\hline $\mathrm{V}$ & Olmué & 5507 & 0.4461 & 0.00553 & $\mathrm{X}$ & Curaco de Vélez & 10204 & 0.4524 & 0.01297 \\
\hline $\mathrm{V}$ & San Antonio & 5601 & 0.4387 & 0.00344 & $\mathrm{X}$ & Dalcahue & 10205 & 0.4542 & 0.00696 \\
\hline V & Algarrobo & 5602 & 0.4528 & 0.00720 & $\mathrm{X}$ & Puqueldón & 10206 & 0.4460 & 0.01157 \\
\hline $\mathrm{V}$ & Cartagena & 5603 & 0.4386 & 0.00546 & $\mathrm{X}$ & Queilén & 10207 & 0.4586 & 0.00965 \\
\hline $\mathrm{V}$ & El Quisco & 5604 & 0.4403 & 0.00648 & $\mathrm{X}$ & Quellón & 10208 & 0.4802 & 0.00874 \\
\hline $\mathrm{V}$ & El Tabo & 5605 & 0.4359 & 0.00693 & $\mathrm{X}$ & Quemchi & 10209 & 0.4643 & 0.00812 \\
\hline V & Santo Domingo & 5606 & 0.4700 & 0.00853 & $\mathrm{X}$ & Quinchao & 10210 & 0.4967 & 0.00888 \\
\hline $\mathrm{V}$ & San Felipe & 5701 & 0.4445 & 0.00352 & $\mathrm{X}$ & Osorno & 10301 & 0.4968 & 0.00390 \\
\hline $\mathrm{V}$ & Catemu & 5702 & 0.4332 & 0.00656 & $\mathrm{X}$ & Puerto Octay & 10302 & 0.4775 & 0.00787 \\
\hline $\mathrm{V}$ & Llaillay & 5703 & 0.4332 & 0.00530 & $\mathrm{X}$ & Purranque & 10303 & 0.4697 & 0.00571 \\
\hline $\mathrm{V}$ & Panquehue & 5704 & 0.4355 & 0.00901 & $\mathrm{X}$ & Puyehue & 10304 & 0.4548 & 0.00715 \\
\hline $\mathrm{V}$ & Putaendo & 5705 & 0.4319 & 0.00583 & $\mathrm{X}$ & Río Negro & 10305 & 0.4634 & 0.00650 \\
\hline $\mathrm{V}$ & Santa María & 5706 & 0.4304 & 0.00668 & $\mathrm{X}$ & San Juan de La Costa & 10306 & 0.4325 & 0.00737 \\
\hline VI & Rancagua & 6101 & 0.4504 & 0.00562 & $\mathrm{X}$ & San Pablo & 10307 & 0.4623 & 0.00875 \\
\hline VI & Codegua & 6102 & 0.4247 & 0.00753 & $\mathrm{X}$ & Chaitén & 10401 & 0.4919 & 0.00964 \\
\hline VI & Coinco & 6103 & 0.4358 & 0.00893 & $\mathrm{X}$ & Futaleufú & 10402 & 0.4676 & 0.01500 \\
\hline VI & Coltauco & 6104 & 0.4237 & 0.00646 & $\mathrm{X}$ & Hualaihué & 10403 & 0.4512 & 0.00793 \\
\hline VI & Doñihue & 6105 & 0.4304 & 0.00620 & $\mathrm{X}$ & Palena & 10404 & 0.4690 & 0.01447 \\
\hline VI & Graneros & 6106 & 0.4386 & 0.00657 & $\mathrm{X}$ & Valdivia & 10501 & 0.5001 & 0.00448 \\
\hline VI & Las Cabras & 6107 & 0.4208 & 0.00605 & $\mathrm{X}$ & Corral & 10502 & 0.4592 & 0.00965 \\
\hline VI & Machalí & 6108 & 0.4589 & 0.00668 & $\mathrm{X}$ & Futrono & 10503 & 0.4733 & 0.00670 \\
\hline VI & Malloa & 6109 & 0.4273 & 0.00708 & $\mathrm{X}$ & La Unión & 10504 & 0.4862 & 0.00512 \\
\hline VI & Mostazal & 6110 & 0.4330 & 0.00615 & $\mathrm{X}$ & Lago Ranco & 10505 & 0.4601 & 0.00769 \\
\hline VI & Olivar & 6111 & 0.4344 & 0.00808 & $\mathrm{X}$ & Lanco & 10506 & 0.4648 & 0.00663 \\
\hline VI & Peumo & 6112 & 0.4351 & 0.00735 & $\mathrm{X}$ & Los Lagos & 10507 & 0.4598 & 0.00503 \\
\hline VI & Pichidegua & 6113 & 0.4168 & 0.00576 & $\mathrm{X}$ & Máfil & 10508 & 0.4713 & 0.00923 \\
\hline VI & Quinta de Tilcoco & 6114 & 0.4222 & 0.00749 & $\mathrm{X}$ & Mariquina & 10509 & 0.4670 & 0.00629 \\
\hline VI & Rengo & 6115 & 0.4407 & 0.00513 & $\mathrm{X}$ & Paillaco & 10510 & 0.4652 & 0.00564 \\
\hline VI & Requínoa & 6116 & 0.4395 & 0.00648 & $\mathrm{X}$ & Panguipulli & 10511 & 0.4732 & 0.00494 \\
\hline VI & San Vicente & 6117 & 0.4423 & 0.00559 & $\mathrm{X}$ & Río Bueno & 10512 & 0.4859 & 0.01423 \\
\hline VI & Pichilemu & 6201 & 0.4347 & 0.00659 & XI & Coihaique & 11101 & 0.5139 & 0.01166 \\
\hline VI & La Estrella & 6202 & 0.4193 & 0.01168 & XI & Lago Verde & 11102 & 0.4831 & 0.02205 \\
\hline VI & Litueche & 6203 & 0.4254 & 0.00910 & XI & Aisén & 11201 & 0.5068 & 0.01366 \\
\hline
\end{tabular}




\begin{tabular}{|c|c|c|c|c|c|c|c|c|c|}
\hline Reg. & County & $\begin{array}{c}\text { Census } \\
\text { Code }\end{array}$ & $\begin{array}{c}\text { Gini } \\
\text { Coef. }\end{array}$ & $\begin{array}{l}\text { Std. } \\
\text { Error }\end{array}$ & Reg. & County & $\begin{array}{c}\text { Census } \\
\text { Code }\end{array}$ & $\begin{array}{l}\text { Gini } \\
\text { Coef. }\end{array}$ & $\begin{array}{l}\text { Std. } \\
\text { Error }\end{array}$ \\
\hline VI & Marchihue & 6204 & 0.4153 & 0.00808 & XI & Cisnes & 11202 & 0.4994 & 0.01520 \\
\hline VI & Navidad & 6205 & 0.4192 & 0.00949 & XI & Guaitecas & 11203 & 0.4878 & 0.02055 \\
\hline VI & Paredones & 6206 & 0.4129 & 0.00807 & XI & Cochrane & 11301 & 0.5096 & 0.01702 \\
\hline VI & San Fernando & 6301 & 0.4501 & 0.00534 & XI & O'Higgins & 11302 & 0.4732 & 0.03027 \\
\hline VI & Chépica & 6302 & 0.4347 & 0.01375 & XI & Tortel & 11303 & 0.4879 & 0.03486 \\
\hline VI & Chimbarongo & 6303 & 0.4231 & 0.00519 & XI & Chile Chico & 11401 & 0.5065 & 0.01373 \\
\hline VI & Lolol & 6304 & 0.4252 & 0.00952 & XI & Río Ibáñez & 11402 & 0.4826 & 0.01441 \\
\hline VI & Nancagua & 6305 & 0.4243 & 0.00620 & XII & Punta Arenas & 12101 & 0.5217 & 0.00944 \\
\hline VI & Palmilla & 6306 & 0.4302 & 0.01873 & XII & Laguna Blanca & 12102 & 0.5317 & 0.03654 \\
\hline VI & Peralillo & 6307 & 0.4223 & 0.00729 & XII & Río Verde & 12103 & 0.5412 & 0.04603 \\
\hline VI & Placilla & 6308 & 0.4253 & 0.00859 & XII & San Gregorio & 12104 & 0.5028 & 0.02767 \\
\hline VI & Pumanque & 6309 & 0.4098 & 0.01144 & XII & Cabo de Hornos & 12201 & 0.4995 & 0.01777 \\
\hline VI & Santa Cruz & 6310 & 0.4440 & 0.00582 & XII & Antártica & 12202 & 0.4145 & 0.08954 \\
\hline VII & Talca & 7101 & 0.4967 & 0.00779 & XII & Porvenir & 12301 & 0.5238 & 0.01362 \\
\hline VII & Constitución & 7102 & 0.4865 & 0.00664 & XII & Primavera & 12302 & 0.5341 & 0.02869 \\
\hline VII & Curepto & 7103 & 0.4463 & 0.00718 & XII & Timaukel & 12303 & 0.5088 & 0.04143 \\
\hline VII & Empedrado & 7104 & 0.4315 & 0.01075 & XII & Natales & 12401 & 0.5207 & 0.00969 \\
\hline VII & Maule & 7105 & 0.4582 & 0.00745 & XII & Torres del Paine & 12402 & 0.5041 & 0.03358 \\
\hline VII & Pelarco & 7106 & 0.4349 & 0.00813 & XIII & Santiago & 13101 & 0.4696 & 0.00344 \\
\hline VII & Pencahue & 7107 & 0.4454 & 0.00783 & XIII & Cerrillos & 13102 & 0.4732 & 0.00327 \\
\hline VII & Río Claro & 7108 & 0.4315 & 0.00667 & XIII & Cerro Navia & 13103 & 0.4527 & 0.00280 \\
\hline VII & San Clemente & 7109 & 0.4412 & 0.00445 & XIII & Conchalí & 13104 & 0.4656 & 0.00333 \\
\hline VII & San Rafael & 7110 & 0.4416 & 0.00783 & XIII & El Bosque & 13105 & 0.4738 & 0.00574 \\
\hline VII & Cauquenes & 7201 & 0.4793 & 0.00543 & XIII & Estación Central & 13106 & 0.4717 & 0.00273 \\
\hline VII & Chanco & 7202 & 0.4533 & 0.00805 & XIII & Huechuraba & 13107 & 0.5114 & 0.00447 \\
\hline VII & Pelluhue & 7203 & 0.4505 & 0.00863 & XIII & Independencia & 13108 & 0.4684 & 0.00337 \\
\hline VII & Curicó & 7301 & 0.4937 & 0.00626 & XIII & La Cisterna & 13109 & 0.4729 & 0.00305 \\
\hline VII & Hualañé & 7302 & 0.4466 & 0.00722 & XIII & La Florida & 13110 & 0.4733 & 0.00226 \\
\hline VII & Licantén & 7303 & 0.4653 & 0.00932 & XIII & La Granja & 13111 & 0.4551 & 0.00247 \\
\hline VII & Molina & 7304 & 0.4673 & 0.00580 & XIII & La Pintana & 13112 & 0.4480 & 0.00226 \\
\hline VII & Rauco & 7305 & 0.4526 & 0.00849 & XIII & La Reina & 13113 & 0.4760 & 0.00292 \\
\hline VII & Romeral & 7306 & 0.4653 & 0.00800 & XIII & Las Condes & 13114 & 0.4462 & 0.00206 \\
\hline VII & Sagrada Familia & 7307 & 0.4465 & 0.00663 & XIII & Lo Barnechea & 13115 & 0.5057 & 0.00378 \\
\hline VII & Teno & 7308 & 0.4461 & 0.00586 & XIII & Lo Espejo & 13116 & 0.4535 & 0.00299 \\
\hline VII & Vichuquén & 7309 & 0.4465 & 0.01152 & XIII & Lo Prado & 13117 & 0.4637 & 0.00272 \\
\hline VII & Linares & 7401 & 0.4922 & 0.00648 & XIII & Macul & 13118 & 0.4778 & 0.00299 \\
\hline VII & Colbún & 7402 & 0.4440 & 0.00635 & XIII & Maipú & 13119 & 0.4605 & 0.00220 \\
\hline VII & Longaví & 7403 & 0.4339 & 0.00553 & XIII & Ñuñoa & 13120 & 0.4603 & 0.00233 \\
\hline VII & Parral & 7404 & 0.4792 & 0.00570 & XIII & Pedro Aguirre Cerda & 13121 & 0.4967 & 0.02831 \\
\hline VII & Retiro & 7405 & 0.4329 & 0.00572 & XIII & Peñalolén & 13122 & 0.5121 & 0.01056 \\
\hline VII & San Javier & 7406 & 0.4712 & 0.00545 & XIII & Providencia & 13123 & 0.4396 & 0.00231 \\
\hline VII & Villa Alegre & 7407 & 0.4639 & 0.00718 & XIII & Pudahuel & 13124 & 0.4595 & 0.00228 \\
\hline VII & Yerbas Buenas & 7408 & 0.4398 & 0.00648 & XIII & Quilicura & 13125 & 0.4645 & 0.00265 \\
\hline VIII & Concepción & 8101 & 0.5188 & 0.00470 & XIII & Quinta Normal & 13126 & 0.4698 & 0.00356 \\
\hline VIII & Coronel & 8102 & 0.4731 & 0.00346 & XIII & Recoleta & 13127 & 0.4738 & 0.00271 \\
\hline VIII & Chiguayante & 8103 & 0.5152 & 0.00500 & XIII & Renca & 13128 & 0.4572 & 0.00291 \\
\hline VIII & Florida & 8104 & 0.4594 & 0.00719 & XIII & San Joaquín & 13129 & 0.4676 & 0.00292 \\
\hline VIII & Hualqui & 8105 & 0.4683 & 0.00617 & XIII & San Miguel & 13130 & 0.4798 & 0.00336 \\
\hline VIII & Lota & 8106 & 0.4708 & 0.00470 & XIII & San Ramón & 13131 & 0.4576 & 0.00284 \\
\hline VIII & Penco & 8107 & 0.4857 & 0.00570 & XIII & Vitacura & 13132 & 0.4297 & 0.00266 \\
\hline VIII & San Pedro de la Paz & 8108 & 0.5403 & 0.00500 & XIII & Puente Alto & 13201 & 0.4722 & 0.00836 \\
\hline VIII & Santa Juana & 8109 & 0.4532 & 0.00627 & XIII & Pirque & 13202 & 0.5281 & 0.00775 \\
\hline VIII & Talcahuano & 8110 & 0.4933 & 0.00355 & XIII & San José de Maipo & 13203 & 0.5024 & 0.00611 \\
\hline VIII & Tomé & 8111 & 0.5106 & 0.01724 & XIII & Colina & 13301 & 0.5329 & 0.01910 \\
\hline
\end{tabular}




\begin{tabular}{|c|c|c|c|c|c|c|c|c|c|}
\hline Reg. & County & $\begin{array}{c}\text { Census } \\
\text { Code }\end{array}$ & $\begin{array}{l}\text { Gini } \\
\text { Coef. }\end{array}$ & $\begin{array}{c}\text { Std. } \\
\text { Error }\end{array}$ & Reg. & County & $\begin{array}{c}\text { Census } \\
\text { Code }\end{array}$ & $\begin{array}{l}\text { Gini } \\
\text { Coef. }\end{array}$ & $\begin{array}{c}\text { Std. } \\
\text { Error }\end{array}$ \\
\hline VIII & Lebu & 8201 & 0.4936 & 0.00578 & XIII & Lampa & 13302 & 0.4933 & 0.00546 \\
\hline VIII & Arauco & 8202 & 0.5052 & 0.00570 & XIII & Tiltil & 13303 & 0.4638 & 0.00592 \\
\hline VIII & Cañete & 8203 & 0.5092 & 0.00686 & XIII & San Bernardo & 13401 & 0.4821 & 0.00281 \\
\hline VIII & Contulmo & 8204 & 0.4825 & 0.01000 & XIII & Buin & 13402 & 0.4904 & 0.00390 \\
\hline VIII & Curanilahue & 8205 & 0.4806 & 0.00473 & XIII & Calera de Tango & 13403 & 0.5424 & 0.00709 \\
\hline VIII & Los Alamos & 8206 & 0.4663 & 0.00562 & XIII & Paine & 13404 & 0.4808 & 0.00412 \\
\hline VIII & Tirúa & 8207 & 0.5470 & 0.05998 & XIII & Melipilla & 13501 & 0.4830 & 0.00404 \\
\hline VIII & Los Angeles & 8301 & 0.5216 & 0.00463 & XIII & Alhué & 13502 & 0.4521 & 0.00918 \\
\hline VIII & Antuco & 8302 & 0.4731 & 0.01151 & XIII & Curacaví & 13503 & 0.4885 & 0.00525 \\
\hline VIII & Cabrero & 8303 & 0.4744 & 0.00699 & XIII & María Pinto & 13504 & 0.4573 & 0.00919 \\
\hline VIII & Laja & 8304 & 0.5033 & 0.00597 & XIII & San Pedro & 13505 & 0.4406 & 0.00786 \\
\hline VIII & Mulchén & 8305 & 0.4903 & 0.00573 & XIII & Talagante & 13601 & 0.4964 & 0.00429 \\
\hline VIII & Nacimiento & 8306 & 0.4841 & 0.00552 & XIII & El Monte & 13602 & 0.4930 & 0.01591 \\
\hline VIII & Negrete & 8307 & 0.4624 & 0.00834 & XIII & Isla de Maipo & 13603 & 0.4852 & 0.00551 \\
\hline VIII & Quilaco & 8308 & 0.4583 & 0.01042 & XIII & Padre Hurtado & 13604 & 0.4720 & 0.00453 \\
\hline VIII & Quilleco & 8309 & 0.4525 & 0.00768 & XIII & Peñaflor & 13605 & 0.5120 & 0.02866 \\
\hline
\end{tabular}


Figure 1. Poverty and Inequality in Chile, 1987-2003

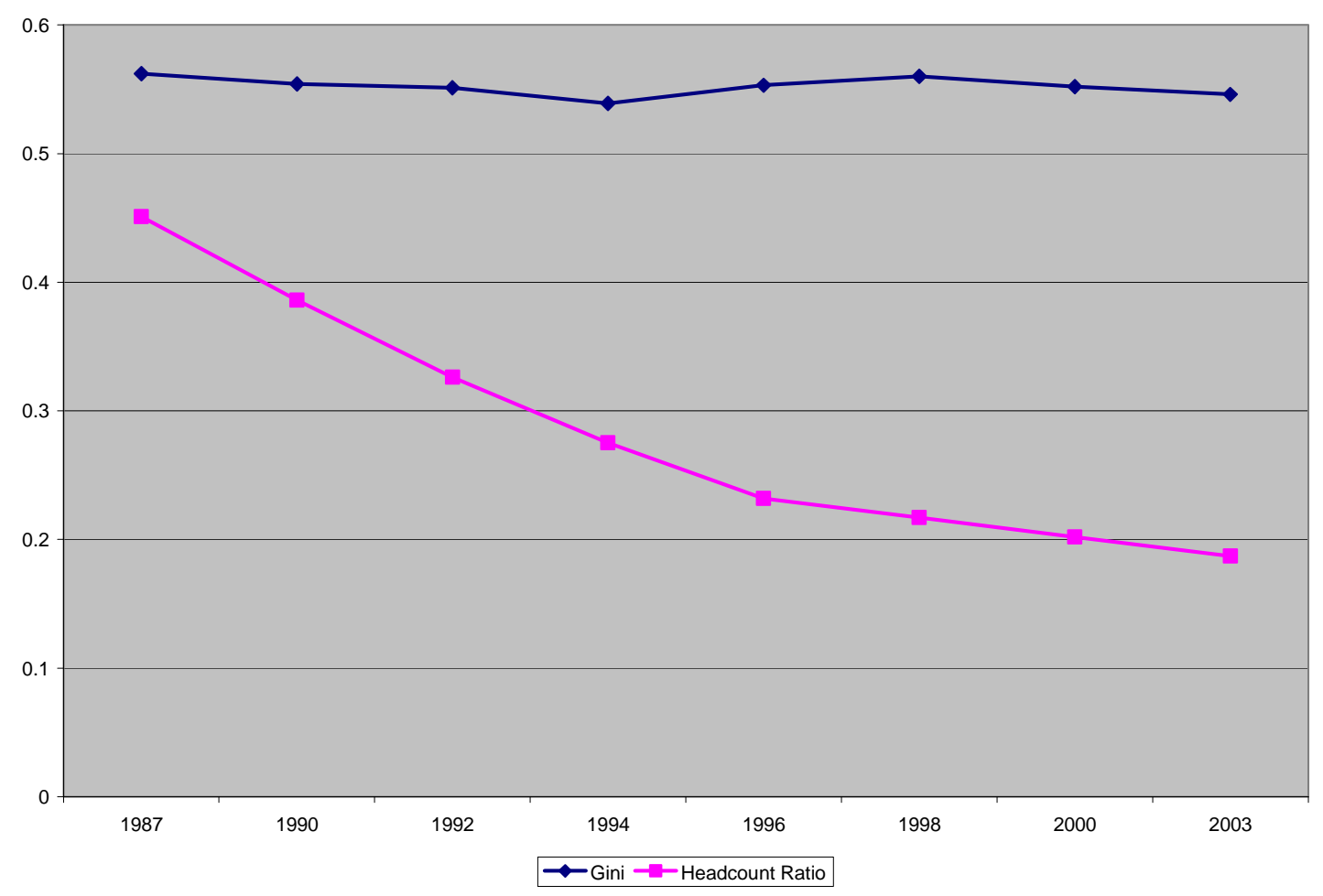

Figure 2. Estimated Ginis in Regions I, II, III, and IV
0.636
0.598
0.561
0.523
0.485
0.447
0.410 
Figure 3. Estimated Ginis in Regions VI, VII, VIII, and IX
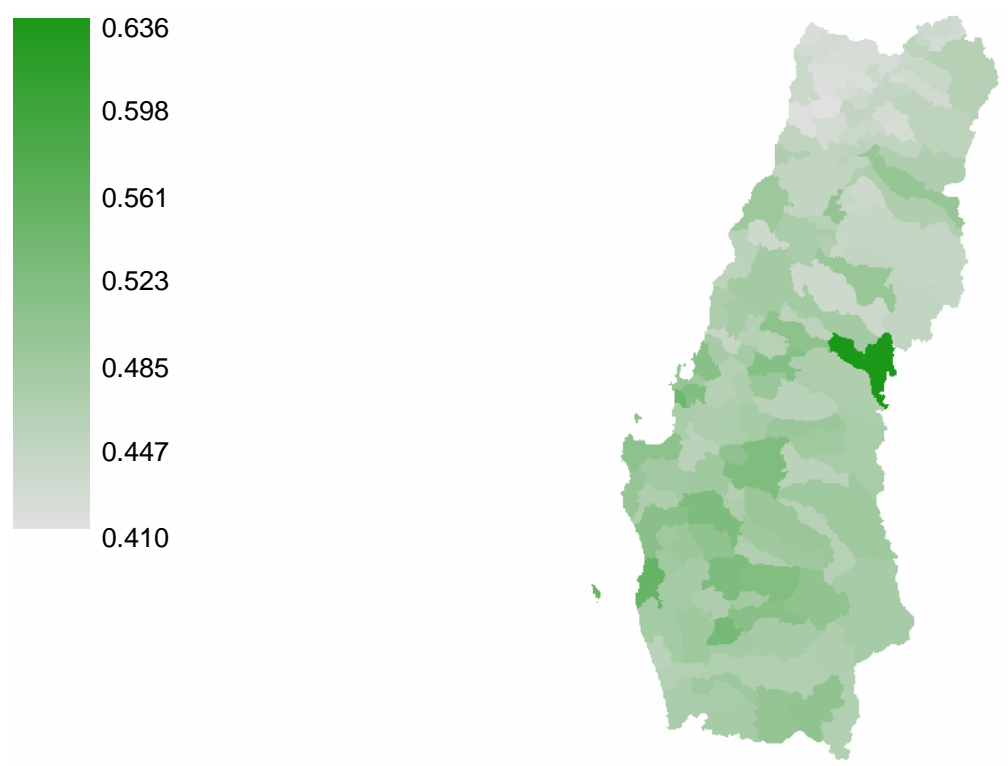

Figure 4. Estimated Ginis in Regions X, XI, and XII
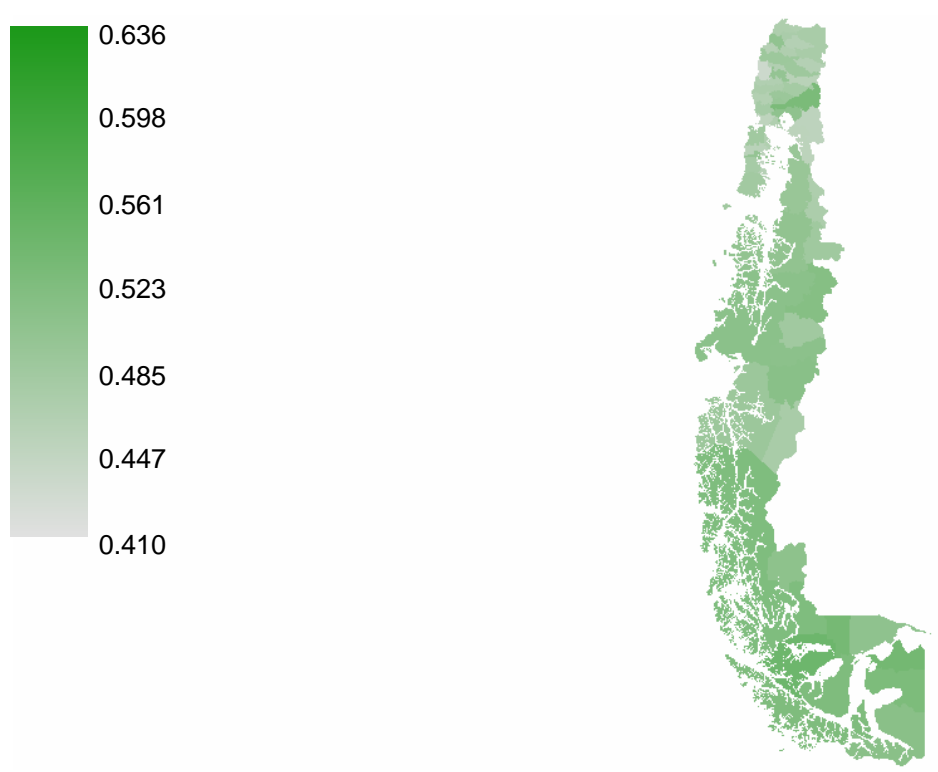
Figure 5. Estimated Ginis in Regions V and XIII

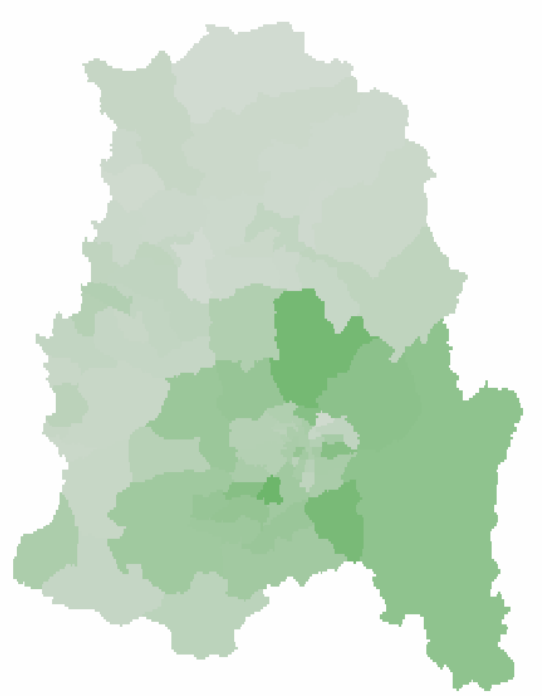

Figure 6. Estimated Ginis with Confidence Intervals

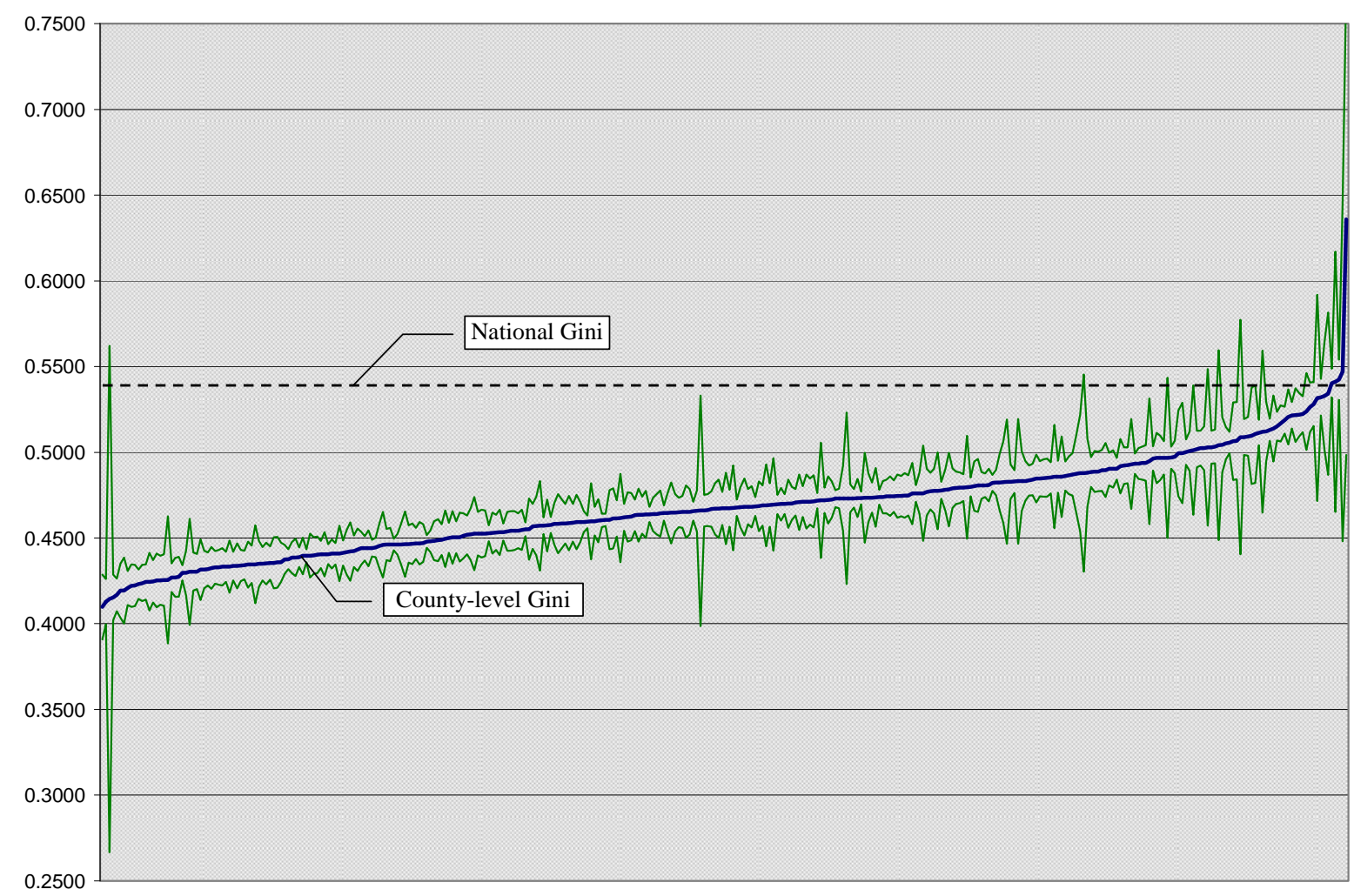


Figure 7: Kernel distribution of Gini coefficients

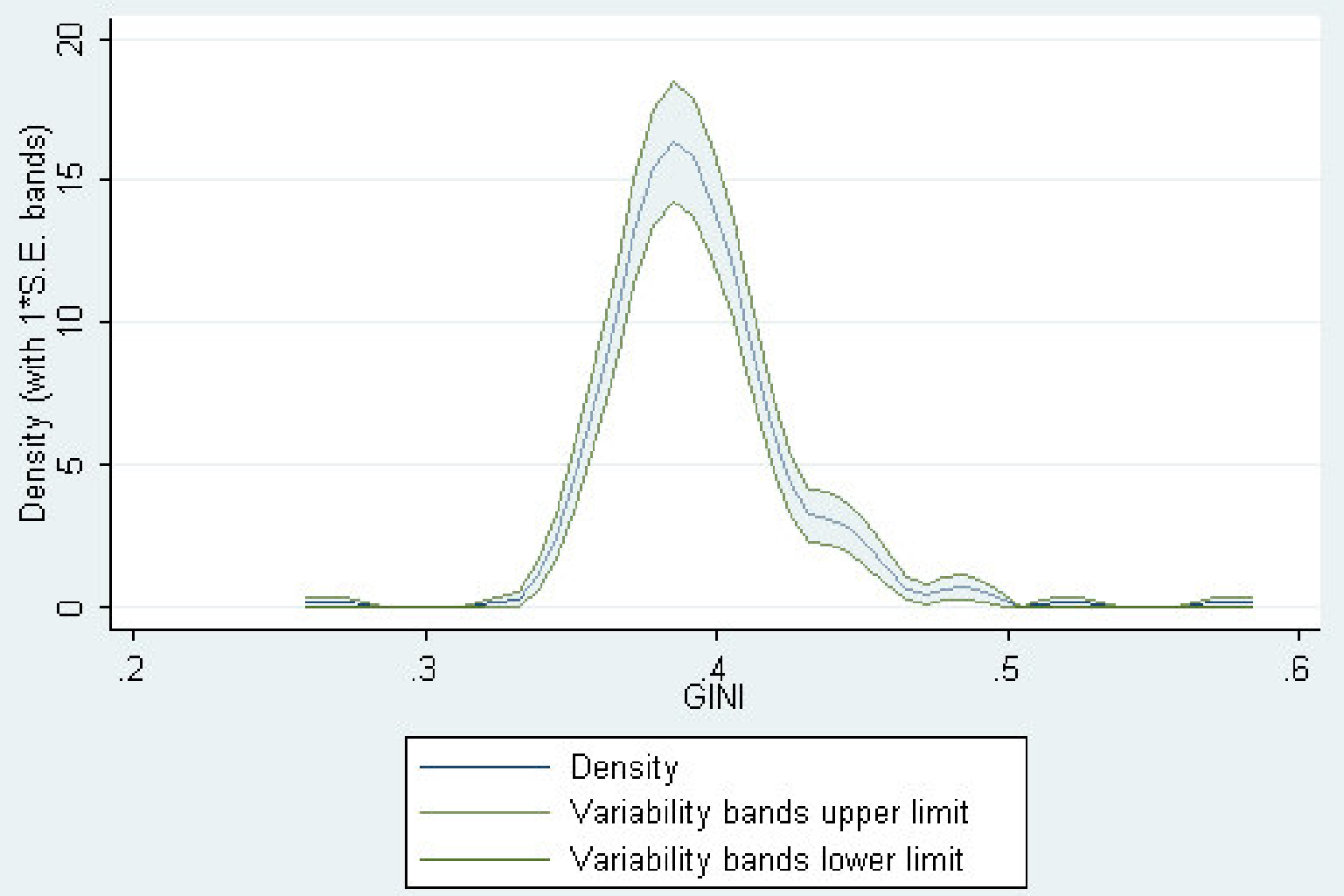

